\title{
Twenty years of carbon accounting and auditing - A review and outlook ${ }^{1}$
}

\author{
Maria Csutora \\ Department of Environmental Economics and Technology, Corvinus University of Budapest, \\ Hungary
}

\section{Gabor Harangozo}

Department of Environmental Economics and Technology, Corvinus University of Budapest, Hungary

Email: gabor.harangozo@uni-corvinus.hu

This paper aims to provide an overview of the key themes in the development of carbon accounting and auditing over the past twentytwenty years. The evolution of the field since the Kyoto Agreement of 1997 has been divided into four stages. The need to account for and disclosure of greenhouse gas-related emissions of industrial organizations has emerged parallel to growing concerns about climate change, and international and national policy developments in the field have followed. Carbon accounting is an emerging field of business economics and covers a wide range of activities, including the measurement, calculation, monitoring, reporting and auditing of greenhouse gas emissions at organizational, process, product or supply chain levels. Various initiatives (such as the Greenhouse Gas Protocol or the Carbon Disclosure Project) motivate and assist industrial organizations in accounting for and reporting their achievements in the field. Different methodologies of carbon accounting (bottom-up, top-down and hybrid) enable industrial organizations to quantify their emissions; however, some tradeoffs emerge when choosing among these approaches. Carbon accounting should not be an isolated task for businesses. On the contrary, there is a strong need to integrate carbon accounting issues into different functional fields in order to achieve both corporate and climate policy goals.

JEL-codes: F23, M14, Q56

Keywords: business administration, business economics, carbon accounting, carbon auditing, industrial organization, sustainable development.

\footnotetext{
${ }^{1}$ The authors would like to thank the OTKA Hungarian Research Fund (116472) for providing support.
} 


\section{INTRODUCTION - THE CONTEXT OF CARBON ACCOUNTING AND REPORTING IN RELATION to Climate Change}

In parallel with global developments, carbon accounting at the organizational level emerged as a field of interest to both academics and practitioners. This paper aims to provide an overview of the key themes in corporate carbon accounting and auditing of the past twenty years, starting in 1997, when the Kyoto Agreement, a fundamental milestone of global climate efforts was accepted, and the Environmental Management Accounting Network (EMAN), a major advocate of organizational-level environmental management, and later carbon accounting, was founded.

In recent decades, climate change has become one of the world's six major sustainability problems alongside deforestation, loss of biodiversity, overpopulation, poverty, and the scarcity of drinking water; and possibly its most fundamental one (e.g., IPCC 2007, Stern 2007). The main reasons behind - and the impacts of - climate change are directly linked to economic and social activities, such as the burning of fossil fuels for generating electric power, transportation, heating and industrial uses, as these activities are the main sources of carbon dioxide emissions globally (IEA 2011). Fighting climate change is thus a core topic in sustainable development (Banuri 2009).

Despite the necessity of reducing carbon emissions, overall greenhouse gas releases have increased world-wide (Siskos 2003). This is largely due to the staggering growth of large emerging economies such as China and India, while other large economies, particularly the United States, have not been sufficiently willing or able to reduce their already exceedingly high emission levels. In addition to international efforts, different national strategies can be observed (e.g., Karlsson et al. 2011; Hovi et al. 2010). A few countries with very high greenhouse gas emission levels, such as Germany and the Netherlands, are moving forward to reduce their emissions (IEA 2011), whereas some vulnerable nations (like the Coalition of Pacific Island States) are urging the international community to take action, while others, such as Australia or China, are observing and following late. Recent developments at the Paris Climate Summit show that most countries now seem to be open to reducing their carbon emissions (UNFCCC 2016). By 2016, 175 countries had signed the agreement; however, there was limited willingness to accept binding targets.

In the last 20 years, various European countries have been successful in decoupling greenhouse gas (GHG) emissions from GDP growth (EEA 2010). At first glance, this suggests that climate policy is succeeding in Europe, setting an example for other parts of the world. Other regions and large economies have continued to increase their carbon dioxide $\left(\mathrm{CO}_{2}\right)$ emissions, with China, for example, releasing a major portion of global greenhouse gas emissions over the last two decades (WRI 2011). The European achievement of curbing carbon emissions while maintaining economic growth, however, is only partially a 'real' improvement in efficiency and emission reductions. Some of the carbon emissions can be said to have been 'exported' with the shift of industrial production to Asia. Weber et al. (2008) reveal that in 2005, around one-third of Chinese emissions were related to the production of exports and that this share has been increasing rapidly in the $21^{\text {st }}$ century. For example, in the case of Hungary, this type of carbon import from China increased six-fold between 2000 and 2008 (Csutora - Vetőné 
Mózner 2014). Furthermore, substantial differences exist across industries. Whereas the manufacturing sector in Europe has reduced its climate impact over the last twenty years, the transport sector has caused a rapid growth in emissions for the same period (IEA 2011). This reflects both globalization and the increasing role of trade through the relocation of manufacturing industries to Asia. Similar developments can be noted in the United States, where carbon emissions have been exported with the shift of industrial production to Asia.

During the last twenty years, organizational-level carbon accounting has undergone a major transformation, from being merely a well-defined example of a broad functional issue to becoming a special focus area of environmental management accounting. This development and transformation of carbon accounting can be divided into four stages, which will be described in this paper in order to provide added value compared to earlier reviews (for example, Schaltegger and Csutora 2012 offer a conceptual perspective but do not address climate change accounting, and Stechemesser and Günther 2012 mainly discuss definitional issues). Moreover, this paper sheds light on the complexity of the issue and the difficulties we face when trying to provide a good estimate of total carbon or climate costs related to business activity.

Section 2 covers the conceptual framework and the four stages of carbon accounting. Section 3 highlights the main approaches to carbon accounting (process-based, input-output modelingbased and hybrid), discusses the issue of system boundaries and reflects on recent developments in carbon reporting. Section 4 stresses the practical relevance and further implications of carbon accounting and reporting for businesses. Finally, Section 5 presents concluding remarks and an outlook on future tendencies in the field, with a special focus on challenges from both academic and business perspectives.

\section{THE CONCEPT AND STAGES OF CARBON ACCOUNTING}

Climate change and international climate policy create a strong demand for measuring and managing the carbon emissions of different socio-economic spheres, starting with the publication of greenhouse gas data. There is no single, clear definition of carbon accounting (Stechemesser - Günther 2012); rather, it covers a wide range of activities related to the calculation, measurement, verification, reporting, etc. of carbon emissions (Burritt - TingeyHolyoak 2012).

Schaltegger and Csutora (2012) distinguish among scientific, political, economic, and corporate levels of carbon accounting. In their approach, scientific carbon accounting covers the major tendencies in emissions, raises awareness and offers references for how carbon emissions can be managed and reduced to remain within the scope of sustainability. Political and economic carbon accounts contribute to the translation of ecological information into economic terms and policy tools and are thus oriented to the business sector. Last but not least, companies can use their carbon accounts as a basis for implementing actions to improve their performance in relation to their climate change impact. Stechemesser and Günther (2012) highlight international, national, industry and corporate levels of carbon accounting, again stressing the potentially different scopes of the field. At the corporate level and as a 
management concept, Schaltegger and Csutora (2012) suggest the term carbon management accounting instead of simply carbon accounting.

Ascui and Lowell (2011) summarize the broad concept of carbon accounting as shown in Table 1.

Table 1. Definition of carbon accounting

\begin{tabular}{|c|c|c|c|c|c|c|c|c|c|}
\hline $\begin{array}{l}\text { estimation } \\
\text { calculation } \\
\text { measurement } \\
\text { monitoring } \\
\text { reporting } \\
\text { validation } \\
\text { verification } \\
\text { auditing }\end{array}$ & of & $\begin{array}{l} \\
\text { carbon } \\
\text { carbon } \\
\text { dioxide } \\
\text { greenhouse } \\
\text { gases }\end{array}$ & $\begin{array}{l}\text { emissions to the } \\
\text { atmosphere } \\
\text { removals from the } \\
\text { atmosphere } \\
\text { emission rights } \\
\text { emission obligations } \\
\text { emission reductions } \\
\text { legal or financial } \\
\text { instruments linked to the } \\
\text { above } \\
\text { trades/transactions of any } \\
\text { of the above } \\
\text { impacts on climate } \\
\text { change } \\
\text { impacts from climate } \\
\text { change }\end{array}$ & at & $\begin{array}{l}\text { global } \\
\text { national } \\
\text { sub-national } \\
\text { regional } \\
\text { civic } \\
\text { organizational } \\
\text { corporate } \\
\text { project } \\
\text { installation } \\
\text { event } \\
\text { product } \\
\text { supply chain }\end{array}$ & $\begin{array}{c}\text { level, } \\
\text { for }\end{array}$ & $\begin{array}{l}\text { mandatory } \\
\text { voluntary }\end{array}$ & $\begin{array}{l}\text { global } \\
\text { national } \\
\text { sub-national } \\
\text { regional } \\
\text { civic } \\
\text { organizational } \\
\text { corporate } \\
\text { project } \\
\text { installation } \\
\text { event }\end{array}$ & purposes \\
\hline
\end{tabular}

Source: Authors, based on Ascui and Lovell (2011: 980.).

However, even a broad definition fails to cover the issue in its entirety. Buritt et al. (2011) and Ascui and Lowell (2012) stress the link between the physical and monetary aspects of carbon accounting.

For the last twenty years, carbon accounting issues have been on the agendas of businesses as well as academics in the academic field of environmental management accounting. However, the focal points and questions of carbon accounting have shifted significantly during this period. Therefore, we have classified the development of carbon accounting into four stages, which are surveyed in the following subsections.

\section{Stage 1: Carbon accounting as an example for environmental management accounting}

Originally, environmental management accounting developed its functional rather than its topical areas. These functional areas included physical environmental accounting, material flow cost accounting, financial accounting, reporting, capital budgeting, and others. etc. (see, for example, Schaltegger and Burritt 2000). Carbon-related costs, although seldom mentioned in these terms, have found their place in each of these functional areas, but they have been used more as an example than as a topical issue.

While physical accounting has embraced carbon dioxide and other greenhouse gas emissions (Bennett - James 1998), financial accounting has focused on related financial costs such as carbon taxes and costs of tradable emission permits. Management accounting has gone even further by recording energy costs as environmental resource costs and energy savings as 
environmentally induced benefits (Jasch 2003). This approach - considering energy costs as environmental costs -was a brave and innovative step in moving away from the short-sighted approach that treated environmental costs mainly as treatment costs and penalties. Considering all wasted material and energy as environmental costs was a revolutionary suggestion that many accountants found surprising and challenging. It is no surprise that at this stage, when even these simple concepts were controversial, there was little coverage of carbon accounting and no mention of it as a special focus area.

\section{Stage 2: Carbon accounting as a separate focus topic}

During the second decade of environmental management accounting, increasing attention was paid to the climate and, therefore, to carbon emission issues, which developed into a special focus area of both sustainability research and business practices. Greenhouse gas emissions were no longer treated as one type of airborne emissions but rather as a standalone topical issue within environmental accounting. Thus, we can speak of carbon management accounting - as a specific field of study - starting in the early 2000s.

In the early 2000s, climate change was still not fully accepted as a threat, as the public especially in the developed world - could not directly feel it, or at least could not directly connect carbon emissions to their environmental consequences. However, increased media coverage resulted in growing public interest in the topic. Europe-wide citizen surveys (Eurobarometer 2007; 2011) indicate that climate change was perceived as a top sustainability concern, even if it lost some ground after the financial crisis. Regulatory and political pressures, such as the Kyoto protocol, emissions trading in the EU and carbon taxes like those in Australia (Pellegrino - Lodhia 2012), were accompanied by societal and market pressures to control climate change. Thus, whether or not they believe in climate change, businesses were forced, as a consequence of climate policy and public perception, to measure and manage their carbon emissions and related costs.

Voluntary corporate initiatives have also played an important role in creating change. The measurement and management of GHG emissions are now on the agendas of the top management of leading companies and advanced business associations. Voluntary corporate initiatives have gained attention, carbon management and accounting divisions have been set up in major consulting companies, and professional accounting organizations are defining their approaches to carbon accounting (Ascui - Lovell 2012; Ratnatunga - Balachandran 2009). The growing interest in carbon accounting and reporting has also raised the demand for standardization in the field.

\section{Stage 3: Carbon accounting covering supply chain and product issues}

Although there have been developments in the field of policy regulation and in company-level carbon accounting and management, there is a clear - and even growing - discrepancy between the national efforts taken to combat carbon releases and still-increasing global carbon emissions. 
A large and increasing share of European and US GHG emissions has been embedded in imported goods as a 'carbon rucksack' (von Weizsäcker et al. 1997, von Weizsäcker 2009). Moreover, the $\mathrm{CO}_{2}$-intensity of products has often increased, partially as a result of more stages of transport and longer transportation distances. National carbon accounts, in both developed and developing countries, are therefore distorted with regard to who actually causes the carbon emissions and their related responsibilities (e.g., Bastianoni et al. 2004)

The large and increasing share of GHG emissions 'hidden' in imported goods underlines the importance of calculating carbon emissions and impacts beyond those directly related to the organizations responsible for production. There has been a growing need to include whole supply chains and product life cycles in carbon accounting, including the emissions caused by semi-manufactured products imported by manufacturing industries. The growing complexity and flexibility of supply chains, however, posed substantial challenges to this type of carbon accounting (Schaltegger - Csutora 2012).

Efforts to effectively combat climate change will fail if companies are not engaged in substantially reducing their carbon emissions. International and political institutions have introduced different measures with varying rigidity and scope (Garnaut 2010). The carbon impacts of delocalized production were not captured and measured until the last decade.

At the moment, the dominant and most widely used framework and international standard for carbon accounting is the Greenhouse Gas (GHG) Protocol, developed by the World Business Council for Sustainable Development and the World Resources Institute (WBCSD - WRI 2004; 2011). This protocol goes to great lengths to help organizations include their indirect carbon emissions. According to the GHG Protocol, carbon emissions are usually grouped into different 'scopes'. The three scopes suggested by the GHG Protocol are the following:

- Scope 1: Direct GHG emissions, including sources that are owned or controlled by the company (e.g., emissions from own boilers, vehicles etc.)

- Scope 2: Electricity indirect GHG emissions from the generation of purchased electricity consumed by the company (the protocol considers solely electricity, but other purchased energy - heat or steam - should also be considered here).

- Scope 3: Other indirect GHG emissions based on activities such as external transportation or the use of sold products. Scope 3 is an optional accounting category that allows for the inclusion of all other indirect emissions. The Scope 3 standard of the GHG Protocol (WBCSD - WRI 2011) provides detailed guidance for organizations on how to include their carbon impacts embedded along the value chain. Beyond upstream emissions, Lenzen and Murray (2010) stress the importance of including downstream impacts in organizational carbon footprint accounts as well. To comprehensively account for these carbon emissions is a much bigger challenge compared to Scopes 1 and 2, as will be highlighted in Section 3.

Although Scope 3 emissions account for a significant portion of organizational emissions (Stein - Khare 2009; Downie - Stubbs 2012), indirect CF elements (other than Scopes 1 or 2) are usually underestimated by companies. Matthews et al. (2008) claim that only $14 \%$ of a company's total carbon footprint is covered by Scope 1, and only $26 \%$ is covered by Scopes 1 and 2 among US companies. However, Matthews et al. (2008) consider Scope 3 as too vaguely 
defined and instead suggest Scope 3 (indirect emissions for production) and Scope 4 (indirect emissions for the total life cycle including delivery, use, and end-of-life). Huang et al. (2009) found that indirect GHG emissions along supply chains can account for as much as $75 \%$ of the total GHG emissions of a company. The most cost-effective carbon mitigation strategies cannot be revealed if Scope 3 emissions are neglected (Matthews et al. 2008). Indeed, accounting for and reporting indirect carbon emissions can lead to better management, as corporations are motivated to choose more environmentally friendly options in their production activities and to incorporate reduction aims into their corporate strategies (Ascui - Lovell 2012). The GHG protocol sets the minimum requirement that companies should separately account for and report on scopes 1 and 2 (WBCSD - WRI 2004).

\section{Stage 4: From carbon accounting to climate accounting}

Carbon accounting, in a broader sense, can also refer to a larger set of greenhouse gas groups, which are covered by the Kyoto Protocol: nitrous oxide $\left(\mathrm{N}_{2} \mathrm{O}\right)$, methane $\left(\mathrm{CH}_{4}\right)$, hydrofluorocarbons (HFCs), perfluorocarbons (PFCs) and sulfur hexafluoride ( $\left.\mathrm{SF}_{6}\right)$ (CCAR 2008; OPEN:EU 2010). If the scope of carbon accounting is extended to a broader set of GHGs, the term carbon accounting is somewhat misleading, as other non-carbon-based GHGs (such as $\mathrm{N}_{2} \mathrm{O}$ and $\mathrm{SF}_{6}$ ) are covered as well (Downie - Stubbs 2013; Meisterling et al. 2009). In this sense, the terms GHG accounting - or even global warming accounting - may be considered even more appropriate (compare with Svensson - Wagner 2011 or Northey et al. 2013).

Additionally, the concept of 'climate change accounting' broadens the horizon even further, as it addresses not only emission costs but also climate change mitigation and adaptation costs. Stechemesser et al. (2015) tried to conceptualize and empirically test 'carbon vulnerability accounting', which delineates how climate adaptation impacts corporate accounts (through increased insurance costs or energy consumption as a consequence of climate change). Focus has already been placed on GHG-accounting in a broader sense, but climate change accounting (including adaptation issues) may also come into the spotlight in the future, as climate change becomes an essential element of organizational cost accounting.

The four stages distinguished above are summarized in Table 2.

Table 2. The transformation of carbon accounting in the last twenty years

\begin{tabular}{|l|l|l|l|l|}
\hline Nr. & Stage & $\begin{array}{l}\text { Description of } \\
\text { transformation }\end{array}$ & $\begin{array}{l}\text { Reasons behind } \\
\text { transformation }\end{array}$ & Focus areas \\
\hline 1 & $\begin{array}{l}\text { Environmental } \\
\text { management } \\
\text { accounting }\end{array}$ & $\begin{array}{l}\text { Carbon as an example } \\
\text { of EMA costs or } \\
\text { savings }\end{array}$ & $\begin{array}{l}\text { Increasing interest in } \\
\text { corporate-level environmental } \\
\text { costs (early development as } \\
\text { part of EMA) }\end{array}$ & $\begin{array}{l}\text { Increasing eco-efficiency, as } \\
\text { well as cost savings in the } \\
\text { field of resource use }\end{array}$ \\
\hline 2 & $\begin{array}{l}\text { Carbon } \\
\text { accounting (direct } \\
\text { emissions) }\end{array}$ & $\begin{array}{l}\text { Detachment as a } \\
\text { differentiated focus }\end{array}$ & $\begin{array}{l}\text { Increasing regulatory and } \\
\text { public attention to climate } \\
\text { change }\end{array}$ & $\begin{array}{l}\text { Accounting, auditing and } \\
\text { reporting of organizational- } \\
\text { level carbon emissions }\end{array}$ \\
\hline
\end{tabular}




\begin{tabular}{|l|l|l|l|l|}
\hline 3 & $\begin{array}{l}\text { Carbon } \\
\text { accounting (with } \\
\text { indirect } \\
\text { emissions) }\end{array}$ & $\begin{array}{l}\text { Product and supply } \\
\text { chain perspectives are } \\
\text { integrated: (Scope 2 } \\
\text { and 3 accounting) }\end{array}$ & $\begin{array}{l}\text { Attention to the impacts of } \\
\text { delocalized production and } \\
\text { transboundary impacts }\end{array}$ & $\begin{array}{l}\text { Comprehensive and } \\
\text { systematic coverage of } \\
\text { carbon emissions and related } \\
\text { costs of products and supply } \\
\text { chains }\end{array}$ \\
\hline 4 & $\begin{array}{l}\text { Climate change } \\
\text { accounting }\end{array}$ & $\begin{array}{l}\text { Widening the horizon } \\
\text { from carbon } \\
\text { accounting to climate } \\
\text { accounting }\end{array}$ & $\begin{array}{l}\text { Climate change as evidence } \\
\text { shifts focus from emission- } \\
\text { related cost to climate } \\
\text { adaptation costs }\end{array}$ & $\begin{array}{l}\text { Comprehensive and } \\
\text { systematic coverage of all } \\
\text { climate change-related } \\
\text { impacts and costs of } \\
\text { products and supply chains }\end{array}$ \\
\hline
\end{tabular}

Source: authors.

From a temporal perspective, the stages overlap somewhat, as academic discussion began to address the different issues before they became widespread elements of practice. With this consideration, Stage 1 covers the first decade (late 1990s to early 2000s), while Stage 2 is the dominant approach of the early and mid-2000s. Although indirect carbon emissions (Stage 3) have been the focus of the academic agenda since the mid-2000s, some methodological issues remain unresolved even in the academic discussion (see next chapter), thus, we can argue that this is still an ongoing stage. Last but not least, organizational climate adaptation issues only began to be addressed in the 2010s and will probably become a focus in the future.

\section{Methods AND TOOLS OF CARBon ACCOUNTING}

Fundamentally, there are three major pathways for assessing business-related carbon emissions.

First, the bottom-up approach: also called material-flow-based or process-based life cycle assessment (LCA), this approach focuses on the carbon (or GHG-) emissions of a certain product or organization by analyzing each and every process in which emissions occur. The same logic is also the basis of the ISO 14040 and 14044 LCA standards (ISO 2006a; b). This approach can deliver accurate emissions results; however, the complexity of some activities (car production, for example) that entail several thousand processes can be extremely difficult (Muller - Schebek 2013), and for this reason, a significant portion of the emissions can be disregarded due to lack of data (Lenzen 2000).

Second, the top-down approach: also known as environmentally extended input-output analysis, the input-output model (Leontief 1936) was originally developed in the 1930s to enable analysis of the links between different economic sectors based on transactions between them. This model can be extended by physical units of environmental data and, thus, can be appropriate for carbon accounting purposes as well, as many applications (such as Cagiao 2011 or Townsend - Barrett 2015) underlie it. Furthermore, input-output analysis can be used as a screening tool to reveal the most significant scope 3 emission sources and can also account for the full upstream supply (Murray et al. 2010). This approach can be appropriate for covering carbon emissions along long supply chains (Mózner 2015); however, system boundaries are not properly defined (Ozawa-Meida et al. 2013). 
Third, the hybrid approach: to address the shortcomings of the two traditional approaches above and mitigate, for example, the limitations of data sources, the two previous approaches can also be combined (Crawford 2008). In this sense, 'hybrid' has two meanings: (1) the combination of both physical and monetary units and (2) the combination of process-based and input-output-based data (Suh 2003). Evidence shows that the bottom-up, process-based LCA approach can be better for downstream emissions, while the top-down EEIO approach can better account for upstream emissions (Suh et al. 2004; Bilec et al. 2006). There are many applications of the hybrid approach to carbon accounting. For example, Lenzen (2002) applied it to different Australian industry sectors, while Ozawa-Meida et al. (2013) used it to study the carbon footprint of a British university by including carbon emissions for Scopes 1, 2 and 3.

An important methodological aspect of carbon accounting is the decision of where to set system boundaries (Harangozo et al. 2015) among organizations, activities or products and thus how to allocate responsibilities in carbon management. Focus can be placed on the organizational (Høgevold 2011; Elmualim et al. 2012), product (Baldo et al. 2009), process (Chakraborty Roy 2012; Caro et al. 2013) or supply chain (Lee - Cheong 2011; Babin - Nicholson 2011; Lee 2011) level, or on a combination of the above (Lenzen - Murray 2010; Carballo-Panela et al. 2012).

Figure 1. Scopes of carbon emissions along supply chains in the economy

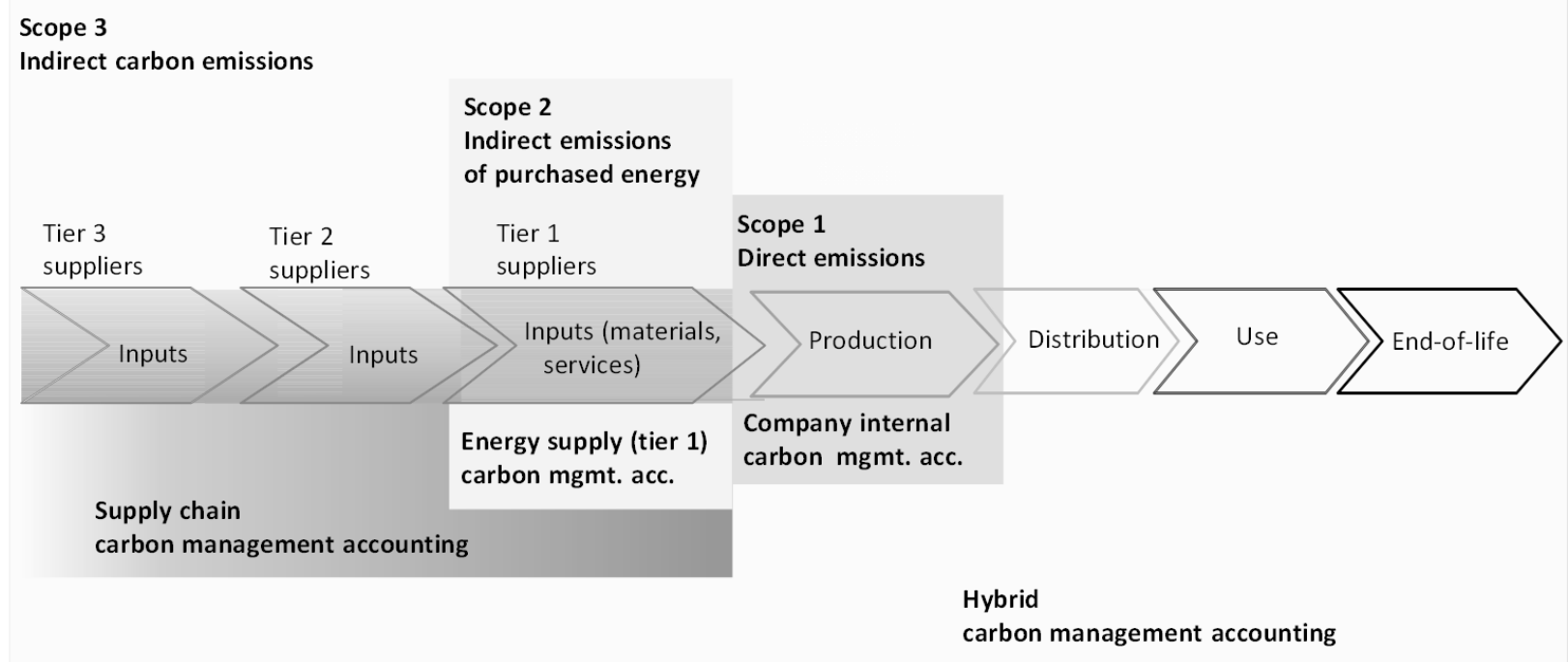

Source: Schaltegger and Csutora (2012: 11).

Figure 1 provides an overview of how carbon emissions can be accounted for along extended supply chains. Production level (Scope 1) carbon emissions can be directly collected based on a bottom-up approach (which was the main tool in Stages 1 and 2 of carbon accounting). To determine further supply chain-level carbon emissions, as is the goal of Stage 3, we need to include Scope 2 and 3 emissions. In most cases, downstream and upstream impacts cannot be precisely calculated, just approximated. Moving away from precise accounting practice 
towards the nebulous field of supply chain carbon impact estimation requires both new methodologies and approaches in thinking.

The bottom-up LCA approach is more accurate, and the system boundaries are better defined, while the top-down approach can deliver data even if there is lack of process-based data, and it does so at substantially lower cost. With the hybrid approach, the benefits of the two can be merged (usually by using the input-output approach for estimations upstream and the bottomup approach for downstream). Last but not least, accounting for climate adaptation impacts and costs (Stage 4) is not covered by the figure. Indeed, a future research field will need to systematically approach these impacts.

An additional tool that is closely related to carbon accounting is carbon (or greenhouse gas) footprinting. A carbon footprint measures the total amount of greenhouse gas emissions that are directly and indirectly caused by an activity (Wiedmann et al. 2009; Jungbluth et al. 2012) or are accumulated over the life stages of a product (Galli et al. 2012). In this sense, an organizational carbon footprint can be approached as the amount of carbon or GHG emissions that are directly or indirectly caused by the organization's processes or emerge over the full life-cycle of the products or services of this organization (Jensen 2012; Townsend - Barrett 2015).

The carbon footprint is usually expressed in terms of physical units ( $\mathrm{g}$, $\mathrm{kg}$ or $\mathrm{t}$ ) of $\mathrm{CO}_{2}$ (WBCSD - WRI 2004; Vázquez-Rowe et al. 2013). If further GHG-emissions are covered as well, $\mathrm{CO}_{2}$ equivalents are calculated (Panela et al. 2009).

The carbon footprint is also used as a component of the ecological footprint (see for example Wackernagel et al. 1999; Toth and Szigeti 2016). In this case, the carbon footprint is measured in land units. However, when converting emissions into land area based on the carbon uptake capacity of ecosystems, a variety of assumptions are applied, which increases uncertainty (Galli et al. 2012). For this reason, physical units are usually preferred in organizational carbon accounting.

Carbon reporting plays an important role in transmitting the results of carbon accounting to stakeholders with very different backgrounds and interests. In the last twenty years, many voluntary frameworks and schemes have been developed that can be used to report the carbon emissions of businesses to investors or other stakeholders.

One major initiative for providing information (mainly to investors) is the Carbon Disclosure Project (CDP). CDP acts on behalf of a coalition of investors and provides an evaluation tool for institutional investors and other stakeholders. In 2014, a total of 5003 companies responded to the CDP questionnaire, compared with 253 in 2003 (CDP 2016). In 2015, the CDP had 827 institutional investor signatories (including banks, pension funds, asset managers and insurance companies) with more than US\$ 100 trillion in assets under management (CDP 2016). Within the CDP, standards have been developed to ensure transparency and comparability in accounting. The CDP also offers a database in which one can search for archived survey responses. The ranking of companies - based on the Carbon Disclosure Leadership Index (CDLI) - does not reflect a company's volume of emissions but rather its accounting methodology and commitment. In 2012, the CDLI comprised 51 companies from the Global 
500 based on the quality of their disclosure and their performance on actions taken to mitigate climate change. The percentage of firms disclosing quality information has not substantially increased over time (Matisoff et al. 2013). The CDP (as well as the Global Reporting Initiative, for example) uses the GHG Protocol as a basis for carbon accounting. Voluntary disclosure is motivated by the emerging needs of different stakeholders - such as investors considering different aspects of corporate social responsibility (Schaltegger et al. 2012; Fu - Ho 2014) or interested in other related fields such as the use of renewable energy (Pollmann et al. 2014) and is supported by different initiatives such as the Carbon Disclosure Project.

Beyond the CDP, the non-profit sector has been very active in promoting additional frameworks that companies can use to account for and report their carbon emissions. The UKbased Carbon Trust - founded in 2001 - has been active in projects all over the world. As of 2016, the Carbon Trust reported saving 60 Mtons of $\mathrm{CO}_{2}$ through its partners' activities (Carbon Trust 2016).

Other schemes for disclosing and reporting GHG-related information to stakeholders are, for example, the Global Reporting Initiative (GRI) and the guidelines of ISO 14031. Based on sustainability (including GHG)-related information reported by companies, ratings such as the Dow Jones Sustainability Index offer investors further evaluations of companies' excellence. A specific form of carbon reporting is product level-carbon labeling (see for example Carbon Trust 2008 or Scipioni et al. 2012).

Voluntary disclosure can be a valuable tool for communicating environmental targets and achievements, although it does not provide sufficient motivation, and targets are often not met (Pellegrino - Lodhia 2012). Exceeding and supplementing voluntary reporting, mandatory reporting might also be an option for sharing business-related carbon emissions with the public. When considering the relatively low interest of companies in voluntary reporting, mandatory reporting may make more sense. There are also examples from practice as well. For example, in Britain, the Department for Environment, Food and Rural Affairs (DEFRA) launched a regulation in 2013 that all companies listed on the stock exchange need to report their Scope 1 and Scope 2 emissions (DEFRA 2013). As a result of this requirement, the authorities expect a decrease in carbon emissions of 4 Mtons by 2021 (Carbon Trust 2016).

Although the move by authorities to include mandatory reporting in regulation seems to be logical, Sullivan and Gouldson (2012) raise three concerns: (1) data consistency and comparability may be lacking, especially if the reporting companies are not motivated to report; (2) the presence of large shares of indirect emissions along the supply chain (Scope 3) is not addressed by this type of reporting; and (3) 'one size fits all' methods disregard the characteristics of individual companies.

The growing interest in carbon accounting and reporting has raised the demand for standardization in the field as well. Beyond the standards-related GHG Protocol, the CDP, and the reporting framework of the GRI, additional international standards have been developed with specific focus areas. The most important ones include the British Standard PAS 2050 for carbon labeling, ISO 14067 for carbon footprinting of products, and ISO 14064 for GHG reporting. As always, standardization raises the issue of the trade-off between comparability and the individual characteristics of companies. 


\section{Relevance For Practice}

So far, we have summarized the conceptual background of carbon accounting and reporting; these practices have also gained relevance for businesses (underpinned by the number of companies voluntarily releasing data or participating in related initiatives such as the CDP). Furthermore, carbon accounting can be relevant and useful to corporate professionals with very different backgrounds. Indeed, it can be applied to almost all corporate functions, as Hiba! A hivatkozási forrás nem található. summarizes. The table highlights (with examples) that goals, challenges, methods and unanswered questions are quite diverse in the various fields, making it a complex task for companies to include them properly. On the one hand, top management may need aggregated information on the total carbon impact of the company and how carbon reduction could support its competitive strategy. On the other hand, marketing, for example, may be interested in carbon labels, certifications and product optimization designs, which create carbon reduction effects for customers through product innovations.

elationship of carbon accounting to different functions of business enterprises

\begin{tabular}{|c|c|c|c|c|}
\hline $\begin{array}{l}\text { Corporate } \\
\text { functions }\end{array}$ & $\begin{array}{l}\text { Carbon policies } \\
\text { (examples) }\end{array}$ & $\begin{array}{l}\text { Challenges } \\
\text { (examples) }\end{array}$ & Methods (examples) & $\begin{array}{l}\text { Implications for } \\
\text { future research } \\
\text { (examples) }\end{array}$ \\
\hline $\begin{array}{l}\text { Strategic and top } \\
\text { management }\end{array}$ & $\begin{array}{l}\text { Competitive } \\
\text { carbon strategies } \\
\text { Corporate policies } \\
\text { to achieve Kyoto, } \\
\text { national and } \\
\text { industry } \\
\text { associations' goals }\end{array}$ & $\begin{array}{l}\text { Low carbon } \\
\text { intensity as a } \\
\text { competitive } \\
\text { factor; climate } \\
\text { neutrality of } \\
\text { company; } \\
\text { increasing cost } \\
\text { of fuels and } \\
\text { ETS regulation }\end{array}$ & $\begin{array}{l}\text { Carbon accounting for } \\
\text { (un-) sustainability re- } \\
\text { porting related to } \\
\text { scientific and political } \\
\text { goals; accounts of } \\
\text { compensation } \\
\text { projects; climate } \\
\text { (neutrality) audits }\end{array}$ & $\begin{array}{l}\text { Development of } \\
\text { carbon competitive } \\
\text { strategy; systems to } \\
\text { achieve overall } \\
\text { carbon impact } \\
\text { reduction; linking } \\
\text { corporate and } \\
\text { international } \\
\text { measures }\end{array}$ \\
\hline $\begin{array}{l}\text { Production } \\
\text { management }\end{array}$ & $\begin{array}{l}\text { Process } \\
\text { improvement } \\
\text { policies }\end{array}$ & $\begin{array}{l}\text { Process and } \\
\text { system } \\
\text { innovations }\end{array}$ & $\begin{array}{l}\text { Carbon accounts of } \\
\text { production processes; } \\
\text { comparative carbon } \\
\text { accounting for } \\
\text { improvements }\end{array}$ & $\begin{array}{l}\text { Software supported } \\
\text { carbon accounting } \\
\text { linked with core } \\
\text { management } \\
\text { information systems }\end{array}$ \\
\hline $\begin{array}{l}\text { Product } \\
\text { management }\end{array}$ & Product policies & $\begin{array}{l}\text { Product } \\
\text { innovations }\end{array}$ & $\begin{array}{l}\text { Product Carbon } \\
\text { Footprint; carbon } \\
\text { reduction labels }\end{array}$ & $\begin{array}{l}\text { Systems to secure and } \\
\text { verify total carbon } \\
\text { impact reduction }\end{array}$ \\
\hline $\begin{array}{l}\text { Supply chain } \\
\text { management and } \\
\text { procurement }\end{array}$ & $\begin{array}{l}\text { Supply chain } \\
\text { policies }\end{array}$ & $\begin{array}{l}\text { Climate } \\
\text { neutrality of } \\
\text { product chains }\end{array}$ & $\begin{array}{l}\text { Supply chain } \\
\text { accounting of carbon } \\
\text { impacts; climate } \\
\text { neutrality labels }\end{array}$ & $\begin{array}{l}\text { Systems to create } \\
\text { and secure overall } \\
\text { carbon neutrality }\end{array}$ \\
\hline Marketing & $\begin{array}{l}\text { Carbon reductions, } \\
\text { carbon neutrality, } \\
\text { low carbon } \\
\text { products, etc. }\end{array}$ & $\begin{array}{l}\text { Development of } \\
\text { carbon neutral } \\
\text { products and } \\
\text { companies }\end{array}$ & $\begin{array}{l}\text { Linking carbon ac- } \\
\text { counting with pricing } \\
\text { and effective } \\
\text { marketing } \\
\text { communication }\end{array}$ & $\begin{array}{l}\text { Successful launch } \\
\text { and positioning of } \\
\text { carbon-superior } \\
\text { products \& services }\end{array}$ \\
\hline Logistics & $\begin{array}{l}\mathrm{CO}_{2} \text {-reduction of } \\
\text { transportation, } \\
\text { storage and } \\
\text { logistics }\end{array}$ & $\begin{array}{l}\text { Technical and } \\
\text { software } \\
\text { challenges of } \\
\text { logistics }\end{array}$ & $\begin{array}{l}\text { Carbon accounts of } \\
\text { transportation systems } \\
\text { and paths }\end{array}$ & $\begin{array}{l}\text { Development of } \\
\text { simple carbon } \\
\text { calculators for } \\
\text { drivers, software, } \\
\text { etc. }\end{array}$ \\
\hline $\begin{array}{l}\text { Public relations } \\
\text { and corporate } \\
\text { communications }\end{array}$ & $\begin{array}{l}\text { Media and NGO } \\
\text { attention; carbon } \\
\text { information as part }\end{array}$ & $\begin{array}{l}\text { Identification of } \\
\text { NGO and } \\
\text { media topics }\end{array}$ & $\begin{array}{l}\text { Stakeholder dialogues } \\
\text { Carbon accounting } \\
\text { fulfilling GRI and }\end{array}$ & $\begin{array}{l}\text { Effective carbon } \\
\text { accounting and } \\
\text { reporting systems }\end{array}$ \\
\hline
\end{tabular}




\begin{tabular}{|l|l|l|l|l|}
\hline & $\begin{array}{l}\text { of sustainability } \\
\text { reporting }\end{array}$ & $\begin{array}{l}\text { Collection and } \\
\text { integration of } \\
\text { carbon } \\
\text { information in } \\
\text { reports }\end{array}$ & $\begin{array}{l}\text { other reporting } \\
\text { requirements (e.g., for } \\
\text { the 'Carbon } \\
\text { Disclosure Leadership } \\
\text { Index') }\end{array}$ & $\begin{array}{l}\text { for un-sustainability } \\
\text { deduced from } \\
\text { stakeholder } \\
\text { expectations }\end{array}$ \\
\hline Finance & $\begin{array}{l}\text { Emissions trading } \\
\text { requirements, } \\
\text { sustainability } \\
\text { ratings, specific } \\
\text { carbon reporting } \\
\text { requirements of } \\
\text { investors and } \\
\text { analysts }\end{array}$ & $\begin{array}{l}\text { Integration of } \\
\text { carbon } \\
\text { information and } \\
\text { performance } \\
\text { into finance and } \\
\text { investor- } \\
\text { relations } \\
\text { strategy }\end{array}$ & $\begin{array}{l}\text { Investor-related } \\
\text { carbon finance and } \\
\text { accounting methods } \\
\text { and certifications }\end{array}$ & $\begin{array}{l}\text { Adaptation and } \\
\text { development of new } \\
\text { finance and } \\
\text { accounting methods } \\
\text { linking carbon } \\
\text { performance with } \\
\text { financial } \\
\text { performance }\end{array}$ \\
\hline HR & $\begin{array}{l}\text { Leading } \\
\text { innovative low } \\
\text { carbon or carbon } \\
\text { neutral companies }\end{array}$ & $\begin{array}{l}\text { Supporting a } \\
\text { workforce } \\
\text { motivated by } \\
\text { carbon } \\
\text { reduction }\end{array}$ & $\begin{array}{l}\text { Identification of } \\
\text { reduction potentials } \\
\text { and formulation of } \\
\text { targets for each job; } \\
\text { involvement of } \\
\text { employees in deve- } \\
\text { loping carbon } \\
\text { reduction }\end{array}$ & $\begin{array}{l}\text { Internal accounting } \\
\text { and reporting, } \\
\text { supporting } \\
\text { awareness, } \\
\text { improvement and } \\
\text { acknowledgement of } \\
\text { achievements }\end{array}$ \\
& & & \\
& & & \\
& & &
\end{tabular}

Source: authors, based on Schaltegger and Csutora (2012: 10).

A key challenge for corporate-level carbon accounting is, therefore, to develop a carbon accounting system that can meet the different needs of all functions in the most efficient manner. Links to strategy and existing management information system(s) are thus to be explored, as they may have the potential to integrate carbon-related accounting with conventional financial accounting information. There are best practices (international standards, e.g., the GHG Protocol discussed earlier, or consultancy from numerous professional organizations, including NGOs) that can lead and guide companies (and even multiple members of value chains) to integrate carbon issues into their various functional fields in order to properly address this challenge A key issue regarding the integration of carbon management into the different functional areas is, however, the motivation of organizations. If proper motivation is missing, the chances are high that carbon accounting - even if present - will remain only an isolated field that is not integrated with other functional areas.

The motivations behind organizational-level carbon management can be grouped into three levels:

- Regulatory-driven: stricter regulation in the field forces companies to integrate carbon accounting into some areas (such as production and product management, and even supply chain management in those industries that have legal expectations at the product level for carbon emissions that are influenced by earlier steps of the supply chain - as in the automotive industry).

- Efficiency-driven: if the potential for cost-savings saving in reduced energy use or carbon emissions (related to carbon quotas) is considered important, a more comprehensive carbon accounting approach is expected to develop at the organizational level, with integration into further functions such as finance and accounting, logistics 
and (at least internal) communication. In this case, mainly Scope 1 and 2 emissions are likely to be covered (where direct costs apply to the organization).

- Market-driven: if market stakeholders along the value chain (final consumers, any B2B customers along the supply chain, or even competitors or suppliers) show interest in carbon issues related to the final products or the supply chain, this is a sufficient motivation to address carbon accounting at the level of strategic management and to integrate it into fields such as marketing (carbon footprint of products), human resources management (how can the organizational footprint be further managed by including the daily practices of all employees) or even PR. When including supply chain impacts (with a strong focus on Scope 3 emissions), the possibility of double accounting is an issue; so, total numbers of different companies along the same supply chain shall not be added mechanically. However, this information can be used for management and responsibility purposes (also based on the principle of shared responsibility).

\section{CONCluSions ANd OUTLOOK}

Parallel to the growing importance of climate change and related international policies, carbon accounting and auditing at the business level have also gained importance in the last twenty years. This review aimed to summarize the temporal development of carbon accounting by dividing the two decades covered into four different stages characterized by different approaches, drivers and focal points. The roots of the concept go back to the emergence of environmental management accounting in the 1990s, but carbon accounting has quickly evolved as its own area within corporate environmental management. Developments in international climate policy have led to the evolution of corporate carbon accounting frameworks and standards covering supply chain and product issues (such as the Greenhouse Gas protocol). Beyond carbon and other greenhouse gas emissions, recent developments in the area tend to also address adaptation issues of climate change.

Although much has been achieved in carbon accounting during this period (from the field's earliest beginnings to its status as a well-established field both in academic discussion and corporate practices), there is still much to do in the future. From a methodological perspective - even if top-down and hybrid approaches to carbon accounting have been worked out - there are still uncertainties regarding how to set system boundaries and avoid double counting while also systematically including supply chain and product-related carbon emissions. So, academic research needs to further focus on refining these issues related to Scope 3 carbon emissions. Another challenge that has emerged recently in the scope of academic discussion and that definitely requires deeper insights from future research is the development of a structural approach to climate change accounting (addressing - beyond merely carbon emissions - the climate adaptation-related impacts of organizations).

Regarding business-related challenges in the field of carbon accounting, the relationship of voluntary and mandatory reporting remains an issue, even though there are good practices in voluntary accounting and reporting (the Greenhouse Gas Protocol or the Carbon Disclosure Project). This type of reporting, however, will not involve the majority of companies in the 
near future, and those with poorer performance in the field are especially likely to stay away, even if their participation would be valuable in moving towards an economy and society that seek not only competitiveness but also welfare in a broader sense (Kerekes 2011; Fodor et al. 2015; Zilahy et al. 2000; Varga 2016). Mandatory reporting might fill this gap to some extent, but it remains to be seen how accurate methodologies can be developed and how comprehensively carbon emissions can be assessed by this type of regulation. Another challenge is related to the resource need of companies to account for their carbon emissions comprehensively. Larger companies may have the financial and human resources to do this; SMEs, however, are very likely to suffer shortages in this context. There are also simpler, freely available carbon calculators on the market, but these are not yet sufficient to provide valid and reliable coverage in the field (Szigeti - Harangozo 2016). So far, academic research has focused on extending the scope and depth of analysis of corporate-level carbon emissions. Parallel to these efforts, academics and practitioners may come up with simpler, but still valid, frameworks designed for the needs of SMEs as well.

\section{REFERENCES}

Ascui, F. - Lovell, H. (2011): As frames collide: making sense of carbon accounting. Accounting, Auditing \& Accountability Journal 24(8): 978-999.

Ascui, F. - Lovell, H. (2012): Carbon accounting and the construction of competence. Journal of Cleaner Production 36: 48-59.

Babin, R. - Nicholson, B. (2011): How green is my outsourcer? Measuring sustainability in global IT outsourcing. Strategic Outsourcing: An International Journal 4(1): 47-66.

Baldo, G. - Marino, M, - Montani, M. - Ryding, S. (2009): The carbon footprint measurement toolkit for the EU Ecolabel. International Journal of Life Cycle Assessment 14(7): 591596.

Banuri, T. (2009): Climate change and sustainable development. Natural Resources Forum 33(4): 257-258.

Bastianoni, S. - Pulselli, F. M. - Tiezzi. E. (2004): The Problem of Assigning Responsibility for Greenhouse Gas Emissions. Ecological Economics 49(3): 253-257.

Bennett, M. - James, P. (eds.) (1998): The Green bottom line: environmental accounting for management: current practice and future trends. Greenleaf.

Bilec, M. - Ries, R. - Matthews, H. S. - Sharrard, A. L. (2006): Example of a hybrid life-cycle assessment of construction processes. Journal of Infrastructure Systems 12(4): 207-215.

Burritt, R. L. - Tingey-Holyoak, J. (2012): Forging cleaner production: the importance of academic-practitioner links for successful sustainability embedded carbon accounting. Journal of Cleaner Production 36: 39-47.

Burritt, R. - Schaltegger, S. - Zvezdov, D. (2011): Carbon Management Accounting. Explaining Practice in Leading German Companies. Australian Accounting Review 21(1): 80-98. 
Cagiao, J. - Gómez, B. - Doménech, J.L. - Mainar, S.G. - Lanza, H.G. (2011): Calculation of the corporate carbon footprint of the cement industry by the application of MC3 methodology. Ecological Indicators 11(6): 1526-1540.

Carballo-Penela, A. - Mateo-Mantecon, I. - Domenech, J. - Coto-Millan, P. (2012): From the Motorways of the Sea to the Green Corridors - Carbon Footprint: The Case of a Port in Spain. Journal of Environmental Planning and Management 55(6): 765-782.

Carbon Disclosure Project, CDP (2016): www.cdp.net, accessed 25 August 2016.

Carbon Trust (2008): Product Carbon Footprinting. The New Business Opportunity. Experiences from Leading Companies. London: Carbon Trust.

Carbon Trust (2016): www.carbontrust.com, accessed 25 August 2016.

Caro, F. - Corbett, C. - Tan, T. - Zuidwijk, R (2013): Double Counting in Supply Chain Carbon Footprinting. Manufacturing Service Operations Management 15(4): 545-558.

CCAR (2008): California Climate Action Registry General Reporting Protocol. California Climate Action Registry, Los Angeles.

Chakraborty, D. - Roy, J (2012): Corporate Carbon Footprint Accounting: Estimating Carbon Footprint of an Indian Paperboard and Paper Production Unit. International Journal of Business Insights \& Transformation 6(1): 18-26.

Crawford, R. H. (2008): Validation of a hybrid life-cycle inventory analysis method. Journal of Environmental Management 88(3): 496-506.

Csutora, M. - Vetőné Mózner, Z. (2014): Proposing a beneficiary-based shared responsibility approach for calculating national carbon accounts during the post-Kyoto era. Climate policy 14(5): 599-616.

DEFRA (2013): Environmental Reporting Guidelines: Including mandatory greenhouse gas emissions reporting guidance. London: UK Department for Environment, Food and Rural Affairs.

Downie, J. - Stubbs, W (2012): Corporate Carbon Strategies and Greenhouse Gas Emission Assessments: The Implications of Scope 3 Emission Factor Selection. Business Strategy \& The Environment 21(6): 412-422.

Downie, J. - Stubbs, W. (2013): Evaluation of Australian companies' scope 3 greenhouse gas emissions assessments. Journal of Cleaner Production 56: 156-163.

EEA (European Environment Agency) (2010): SOER Synthesis, 2010. The European Environment. State and outlook 2010: Synthesis. Copenhagen: Office for Official Publications of the European Union.

Elmualim, A. - Valle, R. - Kwawu, W. (2012): Discerning policy and drivers for sustainable facilities management practice. International Journal of Sustainable Built Environment 1(1): $16-25$.

Eurobarometer (2007): Attitudes of European citizens towards the environment. Special Eurobarometer 295, Summary. Brussels: European Commission. 
Eurobarometer (2011): Attitudes of European citizens towards the environment. Special Eurobarometer 365. Brussels: European Commission.

Fodor, M. - Jäckel, K. - Csiszárik-Kocsir, Á. - Medve, A. (2015): Environment conscious consumers' opinion on selective waste management. The Macrotheme Review: A Multidisciplinary Journal of Global Macro Trends 4(6): 20-33.

Fu, H. J. - Ho, S. Y. (2014): Corporate social responsibility and corporate governance impact on finance performance. Acta Oeconomica, 64(2): 69-77.

Galli, A. - Wiedmann, T. - Ercin, E. - Knoblauch, D. - Ewing, B. - Giljum, S., (2012): Integrating ecological, carbon and water footprint into a "Footprint Family" of indicators. Ecological Indicators 16: 100-112.

Garnaut, R. (2010): Policy Framework for Transition to a Low-Carbon World Economy. Asian Economic Policy Review 5(1): 19-33.

Harangozo, G. - Szechy, A. - Zilahy, G. (2015): Corporate Sustainability Footprints - A Review of Current Practices. In: Schaltegger, S. - Zvezdov, D. - Alvarez, I. E. - Csutora, M. - Günther, E. (eds.): Corporate Carbon and Climate Accounting. Springer International Publishing, pp. 45-76.

Høgevold, N.M. (2011): A corporate effort towards a sustainable business model: A case study from the Norwegian furniture industry. European Business Review 23(4): 392-400.

Hovi, J. - Sprinz, D.F. - Bang, G. (2010): Why the United States did not become a party to the Kyoto protocol: German, Norwegian and US perspectives. European Journal of International Relations 18(1): 129-150.

Huang, Y.A. - Weber, C.L. - Matthews, H.S., (2009): Categorization of scope 3 emissions for streamlined enterprise carbon footprinting. Environmental Science \& Technology 43(22): 8509-8515.

IEA (International Energy Agency) (2011): CO2 emissions from fuel combustions highlights. Paris: IEA/OECD.

IPCC (Intergovernmental Panel on Climate Change) (2007): Climate Change 2007. The physical science basis. Contribution of working group I to the fourth assessment report of the Intergovernmental Panel on Climate Change. Cambridge: Cambridge University Press.

ISO (International Organization for Standardization) (2006a): Environmental managementLife cycle assessment - Principles and framework (ISO 14040:2006). Berlin: Beuth.

ISO (International Organization for Standardization) (2006b): Environmental management Life cycle assessment - Requirements and guidelines (ISO 14044:2006). Berlin: Beuth.

Jasch, C. (2003): The use of Environmental Management Accounting (EMA) for identifying environmental costs. Journal of Cleaner production 11(6): 667-676.

Jensen, J (2012): Product carbon footprint developments and gaps. International Journal of Physical Distribution \& Logistics Management 42(4): 338-354. 
Jungbluth, N. - Büsser, S. - Frischknecht, R. - Flury, K. - Stucki, M (2012): Feasibility of environmental product information based on life cycle thinking and recommendations for Switzerland. Journal of Cleaner Production 28: 187-197.

Karlsson, C. - Parker, C. - Hand, M. - Linnér, B.O. (2011): Looking for leaders. Perceptions of climate change leadership among climate change negotiation participants. Global Environmental Politics 11(1): 89-107

Kerekes S. (2011): Happiness, environmental protection and market economy. Society and Economy 33(1): 5-13.

Lee, K. - Cheong, I (2011): Measuring a carbon footprint and environmental practice: the case of Hyundai Motors Co. (HMC). Industrial Management \& Data Systems 111(6): 961-978.

Lee, K.H. (2011): Integrating carbon footprint into supply chain management: The case of Hyundai Motor Company (HMC) in the automobile industry. Journal of Cleaner Production 19(11): 1216-1223.

Lenzen, M, - Murray, J (2010): Conceptualising Environmental Responsibility. Ecological Economics 70(2): 261-270.

Lenzen, M. (2000): Errors in conventional and input-output based life-cycle inventories. Journal of Industrial Ecology 4(4): 127-148.

Lenzen, M. (2002): A guide for compiling inventories in hybrid life-cycle assessments: some Australian results. Journal of Cleaner Production 10(6): 545-572.

Leontief, W. W. (1936): Quantitative input and output relations in the economic systems of the United States. The Review of Economic Statistics 18(3): 105-125.

Matisoff, D. C. - Noonan, D. S. - O'Brien, J. J. (2013): Convergence in environmental reporting: assessing the Carbon Disclosure Project. Business Strategy and the Environment 22(5): 285-305.

Matthews, H. - Hendrickson, C. - Weber, C., (2008): The importance of carbon footprint estimation boundaries. Environmental Science \& Technology 42(16): 5839-5842.

Meisterling, K. - Samaras, C. - Schweizer, V. (2009): Decisions to reduce greenhouse gases from agriculture and product transport: LCA case study of organic and conventional wheat. Journal of Cleaner Production 17: 222-230.

Mózner, Z.V. (2015): Carbon Accounting in Long Supply Chain Industries. In: Schaltegger, S. - Zvezdov, D. - Alvarez, I. E. - Csutora, M. - Günther, E. (eds.): Corporate Carbon and Climate Accounting. Springer International Publishing, pp. 143-162.

Müller, B. - Schebek, L. (2013): Input-Output-based Life Cycle Inventory. Journal of Industrial Ecology 17(4): 504-516.

Murray, J. - Wood, R. - Lenzen, M., (2010): Input-output analysis - strengths and limitations. In: Murray, J. - Wood, R. (eds): The Sustainability Practitioner's Guide to Input-Output Analysis. Champaign, Illinois: Common Ground Publishing LLC.

Northey, S. - Haque, N. - Mudd, G. (2013): Using sustainability reporting to assess the 
environmental footprint of copper mining. Journal of Cleaner Production 40: 118-128.

OPEN:EU (2010): OPEN:EU Scenario Scoping Report. One Planet Economy Network:

Europe project,

http://www.oneplaneteconomynetwork.org/resources/programmedocuments/Scenario

Scoping Report.pdf, accessed 19 April 2015.

Ozawa-Meida, L. - Brockway, P. - Letten, K. - Davies, J. - Fleming, P. (2013): Measuring carbon performance in a UK University through a consumption-based carbon footprint: De Montfort University case study. Journal of Cleaner Production 56: 185-198.

Pellegrino, C. - Lodhia, S. (2012): Climate change accounting and the Australian mining industry: exploring the links between corporate disclosure and the generation of legitimacy. Journal of Cleaner Production 36: 68-82.

Penela, A. C. - García-Negro, M .C. - Quesada, J. L. D. (2009): A methodological proposal for corporate carbon footprint and its application to a wine-producing company in Galicia, Spain. Sustainability 1(2): 302-318.

Pollmann, O. - Podruzsik, S. - Fehér, O. (2014): Social acceptance of renewable energy: Some examples from Europe and Developing Africa. Society and Economy 36(2): 217-231.

Ratnatunga, J. - Balachandran, K.R. (2009): Carbon Business Accounting: The Impact of Global Warming on the Cost and Management Accounting Profession. Journal of Accounting, Auditing \& Finance 24(2): 333-355.

Schaltegger, S. - Burritt, R. (2000): Contemporary environmental accounting: issues, concepts and practice. Sheffield: Greenleaf Publishing.

Schaltegger, S. - Csutora, M. (2012): Carbon accounting for sustainability and Management. Status quo and challenges. Journal of Cleaner Production 36: 1-16.

Schaltegger, S. - Windolph, S. E. - Herzig, C. (2012): Applying the Known. A Longitudinal Analysis of the Knowledge and Application of Sustainability Management Tools in Large German Companies, Society and Economy 34(4): 549-579.

Scipioni, A. - Manzardo A. - Mazzi, A. - Mastrobuono, M. (2012): Monitoring the carbon footprint of products: a methodological proposal. Journal of Cleaner Production 36: 94101.

Siskos, E. (2003): Economic bases of international mechanisms on climate change. Acta Oeconomica 53(3): 293-306.

Stechemesser, K. - Guenther, E. (2012): Carbon accounting: a systematic literature review. Journal of Cleaner Production 36: 17-38.

Stechemesser, K. - Bergmann, A. - Günther, E. (2015): Organizational Climate Accounting Financial Consequences of Climate Change Impacts and Climate Change Adaptation. In: Schaltegger, S. - Zvezdov, D. - Alvarez, I. E. - Csutora, M. - Günther, E. (eds.): Corporate Carbon and Climate Accounting. Springer International Publishing, pp. 217242. 
Stein, M. - Khare, A. (2009): Calculating the carbon footprint of a chemical plant: A case study of Akzonobel. Journal of Environmental Assessment Policy \& Management 11(3): 291310 .

Stern, N. (2007): The economics of climate change. The Stern review. Cambridge: Cambridge University Press.

Suh S. - Lenzen M. - Treloar G. J. - Hondo, H. - Horvath, A. - Huppes, G. (2004): System boundary selection in life cycle inventories using hybrid approaches. Environmental Science and Technology 38: 657-664.

Suh, S. (2003): Input-output and hybrid life cycle assessment. The International Journal of Life Cycle Assessment 8(5): 257-257.

Szigeti, C. - Harangozó, G. (2016): Online carbon calculators - Corporate carbon footprint analysis in practice. In: Vopava J. - Douda V. - Kratochvil R. - Konecki M. (eds): Conference Proceedings MAC-MME International Conference. Prague, pp. 299.

Sullivan, R. - Gouldson, A. (2012): Does voluntary carbon reporting meet investors' needs? Journal of Cleaner Production 36: 60-67.

Svensson, G. - Wagner, B (2011): A process directed towards sustainable business operations and a model for improving the GWP-footprint (CO2e) on Earth. Management of Environmental Quality: An International Journal 22(4): 451-462.

Toth, G. - Szigeti, C (2016): The historical ecological footprint: From over-population to overconsumption. Ecological Indicators 60: 283-291.

Townsend, J. - Barrett, J. (2015): Exploring the applications of carbon footprinting towards sustainability at a UK university: reporting and decision making. Journal of Cleaner Production 107: 164-176.

UNFCCC (2016): Paris Agreement.

http://unfccc.int/files/meetings/paris_nov_2015/application/pdf/paris_ agreement_english.pdf, accessed 18 August 2016.

Varga, J. (2016): A valódi jólét gazdasága és versenyképességének mérése [The economy of true welfare and the measurement of its competitiveness]. In: Nagy, Z. B. (ed,): LVIII. Georgikon Napok: Felmelegedés, ökolábnyom, élelmiszerbiztonság. Keszthely: Pannon Egyetem, pp. 530-542.

Vázquez-Rowe, I. - Villanueva-Rey, P. - Mallo, J. - De la Cerda, J. - Moreira, T. - Feijoo, G (2013): Carbon footprint of a multi-ingredient seafood product from a business-to-business perspective. Journal of Cleaner Production 44: 200-210.

von Weizsäcker, E. U. - Hargroves, K. - Smith M. H. - Desha C. (2009). Factor five. Transforming the global economy through $80 \%$ Improvements in resource productivity. London: Taylor \& Francis.

von Weizsäcker, E. U. - Lovins, A. B. - Lovins, L. H. (1997): Factor four: doubling wealth halving resource use. London: Earthscan. 
Wackernagel, M. - Onisto, L. - Bello, P. - Linares, A.C. - Falfán, L. - García, J.M. - Suárez, G.A.I. - Suárez, G. M. G. (1999): National natural capital accounting with the ecological footprint concept. Ecological Economics 29(3): 375-390.

WBCSD - WRI (2004): The Greenhouse Gas Protocol - A Corporate Accounting and Reporting Standard. Geneva: World Business Council for Sustainable Development and World Resources Institute.

WBCSD - WRI (2011): The Greenhouse Gas Protocol - Corporate Value Chain (Scope 3) Accounting and Reporting Standard. Supplement to the GHG Protocol Corporate Accounting and Reporting Standard. Geneva: World Business Council for Sustainable Development and World Resources Institute.

Weber, C. - Peters, G. P. - Guan, D. - Hubacek, K (2008): The contribution of Chinese exports to climate change. Energy Policy 36: 3572-3577.

Wiedmann, T. O. - Lenzen, M. - Barrett, J. R. (2009): Companies on the scale comparing and benchmarking the sustainability performance of businesses. Journal of Industrial Ecology 13(3): 361-383.

WRI (World Resource Institute) (2011): CO2 emissions 2011

http://cait.wri.org/cait.php?page=graphcoun\&url=form\&pOpts=open\&pHints=shut\&men

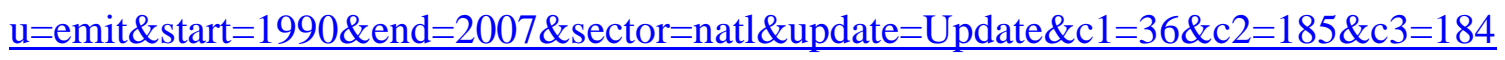
$\underline{\& c 4=85 \& c 5}$, accessed 1 October 2015.

Zilahy, G. - Nemcsicsné Zsóka, Á. - Szeszler, Á. - Urge-Vorsatz, D. - Markandya, A. Hunt, A. (2000): The indirect costs and benefits of greenhouse gas limitations: Hungary Case Study. Roskilde: UNEP-RISO. 